\title{
Underlying factors of recurrent infections in patients with down syndrome
}

\author{
Turkan Patiroglu, Murat Cansever, Fulya Bektas \\ Department of Pediatrics and Immunology, Erciyes University Faculty of Medicine, Kayseri, Turkey
}

\begin{abstract}
Down syndrome is the most common chromosomal aberration. Patientswith Down syndrome suffer more infections than those without the disease. Underlying immunological disorders are consideredto be the reason for the increasing frequency of infections in patients with Down syndrome. In addition, some anatomical abnormalities in the respiratory tractaccompanying Down syndrome can disturb the innate immunity and contribute to the increase in infection rate. Respiratory tract infections are one of the most common causes of mortality in patients with Down syndrome. Awareness of the underlying reason for frequent respiratory tract infections should result in a decrease in mortality among these patients and contribute to an improvementin their quality of life.
\end{abstract}

Keywords: Down syndrome; infections; innate immunity; immune deficiency.

Cite this article as: Patiroglu T., Cansever M., Bektas F. Underlying factors of recurrent infections in Down syndrome. North Clin Istanb 2018;5(2):163-168.

$\mathrm{D}$ own syndrome (DS) is the most common chromosomal aberration. Its frequency varies between $1 / 6000$ and $1 / 8000$ in the Turkish population [1]. It is also the most common genetic reason of mental retardation. DS is also associated with various congenital anomalies such as congenital heart disease (CHD), gastrointestinal anomalies, orthopedic problems alongwith characteristic dysmorphic features. Endocrine and neurologic disorders besides visual and hearing problems can be seen in patients with DS. In addition,hematologic disorders, particularly leukemia; autoimmune diseases such as celiac disease; and type 1 diabetes mellitusis seen in patients with DS. The rise inthe prevalence of both infections and autoimmune disorders are thought to be related to immune disorders [2].

Respiratory tract infectionsare the most commonly observed infection in patients with DS. Furthermore, CHD and respiratory tract infections are important reasons of mortality. Even though many immunologic disorders have been defined in patients with DS, there are still undefined topics in underlying immune deficiency in patients with DS [3]. Immune deficiency may be the reason for frequent respiratory tract infection. In this study, we aimed to review the underlying factors of recurrentinfections inpatients with DS.

The frequency of upper and lower respiratory tract infections is higherin patients with DS than in those without the disease. Pharyngitis and otitis media with effusion are the most commonly diagnosed upper respiratory tract infections and pneumonia as the most commonly diagnosed lower respiratory tract infection. Moreover, pneumonia is the most important cause of hospitalization and mortality inpatients with DS [3]. Secondary respiratory distress syndromedue to pneumonia is higher and severe in children with DS [4].

Respiratory syncytial virus (RSV) is the most commonly observed cause of lower respiratory tract infections and bronchiolitis in infancy and early childhood

Received: January 15, 2017 Accepted: July 30, 2017 Online: January 29, 2018

Correspondence: Dr. Murat CANSEVER. Erciyes Universitesi, Tip Fakultesi, Cocuk Sagligi ve Hastaliklari Anabilim Dalı, Kayseri, Turkey. Tel: +90 5305617837 e-mail: mcansever66@hotmail.com

(c) Copyright 2018 by Istanbul Provincial Directorate of Health - Available online at www.northclinist.com 
[5]. Some studies have shownthat the rate of hospitalization because of RSV infection is higher in patients with D Seven if they do nothavea Congenital Heart Diesase (CHD) [6]. However, there is no explanation about the increased risk of RSVinfection in patients with DS. Staglianao et al. [5] found that length of hospital stay is longer and requirement of respiratory support is much higherin patients with DS during RSV infection. RSV has no specific treatment, but in infants at a risk of RSV (e.g., prematurity, bronchopulmonary dysplasia, CHD, etc.) palivizumab (monoclonal antibody against RSV) is used prophylactically for reducing hospitalization and/or its duration and need for respiratory support. Recently, prophylactic use of palivizumab has been recommended for patients with DS [7]. Hao Yi et al. [7] used palivizumab prophylaxis to prevent RSV infections in patients with DS and demonstrated that palivizumab prophylaxis shortens hospitalization duration in patients with DS.

The risk of serious infections occurring in patients with DShas been found to beincreased compared with the normal population [8]. Studies show that the risk of mortalitydue to sepsis is higher in children with DS [8].

1) Non-Immunologic Causes of Increased Infections in Patients with DS: It is assumed that some dysmorphic features in affected individuals andanatomicalabnormalities contribute to the frequency of infections in patients with DS (Table 1) [2].

\section{Anatomical Abnormalities in Children with DS}

Laryngomalacia, narrowed trachea, tracheomalacia, tracheal stenosis, and subglottic stenosis are the most frequently encountered congenital anomalies in patients with DS. Airway narrowingis caused by various reasons

TABLE1. Abnormalities (nonimmunological) known to increase the incidence of infections in patients with Down syndrome

Anatomical abnormalities of the airways

Obstructive sleep apnea

Congenital anomalies of the lower respiratory tract

Congenital heart disease

Congenital ear anomalies

Gastroesophageal refluxand deglutition disorders in patients with DS. Bertrand et al. [9] foundanatomical abnormalities in the airways in $75 \%$ of patients with DSwho underwent bronchoscopy because of lowerrespiratory tract infections. The mostly common seen abnormality among these is laryngomalacia [10]. Subglottic stenosis is another frequently seen abnormality, which occurs post-intubation [11].

Another important cause of airway narrowing seen in patients with DS is phenotypic findings specific to the syndrome. When the nasopharynx is narrowerthan usual, sinusitis formation and nasal congestion occurs. Hypoplasia of the nose and sinus contributes to nasal obstruction, and repetitive nasal congestion occurs. Adenotonsillar hypertrophy, macroglossia, and choanal stenosis also contribute to narrowing of the airways [2].

Tracheal bronchus, which originates from the trachea, is described as an accessory bronchus. It has been shown that tracheal bronchus is associated with repetitive right lower lobe pneumonia [12]. The frequency of tracheal bronchus abnormality with repetitive right lower lobe pneumonia caused by it is high in patients with DS. Congenital anomalies of the airways cause both repetitive wheezing and coughing, increased risk of respiratory tract infection, and pulmonary hypertension [13]. Creating awareness in patients with congenital airway malformations will contribute to the treatment of patients.

Sleep-related respiratory disorders are one of the most commonly seen respiratory disorders in patients with DS. The rate of obstructive sleep apnea is $30 \%-80 \%$ [14]. Hypoplasia of the nose and sinus, narrowness of the upper respiratory tract, macroglossia, mandibular hypoplasia, adenotonsillar hypertrophy, and obesity are factors that contribute to the development of obstructive sleep apnea in patients with DS. Although adenotonsillectomy provides improvement in symptoms, obstructive sleep apnea may continue in patients with structural airway abnormalities [14]. Even though these patients are asymptomatic, they should be assessed using polysomnography for obstructive sleep apnea. Above all, obstructive sleep apnea may lead to pulmonary hypertension and cor pulmonale by causing intermittent hypoxia and respiratory acidosis.

An autopsy study performed in patients with DS showed that there was a smaller number of alveoli with largened alveoli in the lungs [15]. Because subpleural cyst is another finding, which is a lung parenchymal abnormality, its frequency is highin patients with DS [15].

CHD is one of the main problems causing morbidity in patients with DS (approximately $40 \%$ of patients) 
[16]. The most frequently observed types of CHD are atrioventricular septal defect, atrial septal defect, and ventricular septal defect. Faria et al. [17] found that the risk of serious infections such as pneumonia and sepsis in patients with DS with CHD is considerably higher than in those without $\mathrm{CHD}$.

Chronic otitis and hearing loss are more frequently seen in patients with DS [18]. These may be caused by a variety of anatomical defects. A study showeda stenosis of the external auditory canal in approximately $50 \%$ of patients with DS [19]. Small width of the Eustachian tube and its increased cylindricity leads to collection of more fluid in the middle ear. This contributes to chronic otitis formation $[18,20]$. Barr et al. [21] showed that the frequency of middle ear infections in patients with DS aged $>1$ year rises up to $93 \%$. Moreover, repetitive middle ear infections lead to hearing loss [20].

Gastroesophageal reflux may lead to chronic lung inflammation and bronchospasm. It has also been known that recurrent silent aspiration of gastric fluid causes recurrent respiratory tract infections [22]. It is thought that hypotony, which is seen in patients with DS,reduces pharyngeal muscle tonus and increases the risk of aspiration [22]. The frequency of gastroesophageal reflux disease in patients with DS is higher than that in those with out the disease [22]. There is an increased frequency of esophageal atresia in patients with DS, and disturbed physiological mechanisms after surgery lead to respiratory complications, such as pneumonia, asthma, and high rates of hospitalization due to respiratory tract infections [23].

2) Immune Disorders in Children with DS: Immunity is defined as the body's defense against infectious diseases. It consistsof natural/innate immunity (first protectivebarrier against infectious diseases) and acquired immunity (provides specific and more effective defenses against infections) [24].

Innate immunity provides the first defense when a foreign microorganism appears in the body. It exists in every person from birth and is fast. Becauseit cannot form memory cells, it gives the same response in each case and is not specific to any microorganism [24]. Normal anatomical development and normalphysiological process of organs arean essential part of innate immunity. Several innate and acquired immune disordershave been reported in children with DS (Table 2) [24].

To date, a reduction in neutrophil chemotaxis in patients with DS has been shown in many studies [25]. In addition, the cause of chemotaxis reduction has not yet been fully clarified. On the other hand, studies on neutrophil functions (especially in patients with DS who have recurrent periodontitis) indicate that there are no significant problems in neutrophil oxidative burst reaction or in phagocytosis capacity [25]. Another problem in natural immunity is the decrease in absolute number of monocytes [26]. A study by Bloemers et al. showed that even though the number of absolute monocyte is low, the number of CD14+CD16+ monocytes (a subset of monocytes) is higher in patients with DS. It is well known that monocytes belonging to this subgroup are very effective in the event of proinflammation. This situation may be responsible for the chronic inflammatory events observed in patients with DS [26].

NK anddendritic cells are another important part of innate immunity, and dendritic cells are also responsible for the delivery of antigens to $\mathrm{T}$ helper cells. It has been

TABLE2. Major immune system disorders in patients with Down syndrome

Natural/innate immunity

Decreased neutrophil chemotaxis

Decreased number of NK cells

Decrease in the absolute number of monocytes

Decrease in the number of dendritic cells

Reduction in mannose-binding lectin level
Acquired immunity

Decrease in the number of T cells (particularly naive T cells)

Low number of $B$ cells

Lack of memory cell formation

Lack of T cell proliferation

Size of the thymus is smaller than normal

Inadequate antibody response to vaccination

Decrease in the levelof humoral IgA

Low levelof IgM, IgG2, and IgG4-type antibody 
shown that the numbers of these two cells are significantly lower in patients with DS than in those without the disease [26]. Another disorder in innate immunity in patients with DS is the lackof mannose-bindinglectin (MBL). MBL starts the lectin-dependent pathway of the complement system and acts as opsonin for phagocytosis. MBL deficiency is one of the most common immune deficiencies. There is an increased frequency of infections especially with extracellular pathogensdue to MBL deficiency. Nisiharaet al. [27] showed that the MBL level was lower in children with DS. In particular, regarding repetitive respiratory tract infections in patients with $\mathrm{DS}, \mathrm{MBL}$ deficiency is much more common than in those who do not have recurrent infections [27].

Acquired immunity isalso known as acquired and specific immunity. Response is specifically formed against unique microorganisms. Its effect is slower but more powerful. It can create a stronger response when faced with the same microorganism again by its ability to create memory cells. Although all types of lymphocytes are produced in the bone marrow, $\mathrm{T}$-lymphocytes mature in the thymus and B cells mature in the bone marrow [24].

Various studies have shown that total lymphocyte and T-lymphocyte counts arelow in patients with DS. A low level of T-lymphocytes is also reflected in the T-lymphocyte subsets. The levels of both CD4+ T-lymphocytes and CD8+ T-lymphocytes are low in patients with DScompared with those without the disease. Thissituation wasespeciallyseen in the naive $T$ cells and becomes apparent in the first 2 years of life. The number of T-lymphocytes increases with age and eventually reaches normal levels [28]. The primary expansion of T- and B-lymphocytes was severely defectivein children with DS [29]. In addition, it has been reportedthat the $\mathrm{T}$-cell receptorexcision circle, which reflects the number of naive $T$ cells secreted from the thymus was low in patients with DS $[28,29]$.

Early aging, decreased thymic production, intrinsic defects, and one or more mechanisms of apoptosis are responsible for the reduction in the number of T-lymphocytes. Kusters et al. [30] stated that naive T-lymphocytes have a low rate and memory $T$ cells have a normal rate of reduction. Therefore, they claimed that the reason for the reduction in the number of T-lymphocytes isan intrinsic defect in patients with DS. Bloemers et al. [28] conducted a study to determine the reason for the decrease inthe number of naive $T$ cells. They concluded that reduced thymic production is responsible for the decrease in the number of naive $T$ cells $[28,29]$. In severalstudies, it has also been shown that areduction in the number of naive $T$ cells is not associated with frequent infection [28, 29]. Regulatory $T$ cells are responsible for both the elimination of autoreactive $\mathrm{T}$ cells, which get rid of negative selection from the thymus, and suppression of inflammatory response. The effect of regulatory $T$ cells on the increased frequency of autoimmune diseases in patients with DSwas studied; Pellegrini et al. [31] showed that the number of regulatory $\mathrm{T}$ cellswas higher but their functions weredefective.

A reduction in the number of T-lymphocytes (especially naive T-lymphocytes) was associated with pathology in the thymus where T-lymphocytesmature. Therefore, some studies focused on the development of the thymus. Studies have revealed that the thymus gland is very small inpatients with DS even in newborns [32]. Levin et al. [33] reported cortical atrophy in the thymus, corticomedullary border loss, defect of thymocyte development, and expansion of Hassall's corpuscles in patients with DS. Although there was a defect in thymocyte maturation, mature CD $3+$ and TCRa + cells were present in the blood [28].

The number of B-lymphocytes in patients with DS is lower than that in those without DS. In contrast to T-lymphocytes, thissituationdoes not improve with age. Furthermore, the proliferation and maturation of lymphocytes are not observed in these patients, which were normally seen in the first years of life. Studies related to B-lymphocyte subsets showed that there is a decrease in $\mathrm{CD} 27+\mathrm{IgM}+$ memory B cells, natural effector B cells, CD27+ IgA+, and CD27+ IgG+ memory cells [34]. Despite the problems of memory B cells,plasma cells are present in normal numbers and lymph nodes are not defective in the germinal centers [35]. It is thought that one of the reasons for frequent infections is the reduction in class-switching and thedecreasing number of memory $\mathrm{B}$ cells, which are responsible for effective response to vaccination. Carsetti et al. [34] described an imperfection in B-lymphocytes based on a defect in the maturation of B-lymphocytes. Valentini et al. [36] evaluated antibody production and memory $\mathrm{B}$ cellsthat perform classswitching after polysaccharide vaccine. They stated that there is no problem in terms of antibody production after vaccination, but they showed that there was no success in terms of the production and maintenance ofclassswiched B cells.

The immunoglobulin ( $\mathrm{Ig}$ ) levels and IgG subclasses of patients with DS were evaluated several times. Stud- 
ies have revealed that the $\operatorname{IgA}$ and $\operatorname{IgG}$ levels were normal,butthe IgM level was decreased [35, 36]. Subgroups IgG1- and IgG3-type antibodies, which are effective in the fight against viruses, were at normal or high levels. $\mathrm{IgG} 2$ and IgG4, which are effective in response to bacterial polysaccharide antigen,were at low levels [37].

\section{Summary}

It is known that frequent infections, particularly respiratory tract infections, areincreasedin patients with DS. Both anatomical and immunological problems associated with DS are thought to be the reason for this. These anatomical problems can be classified as anatomical abnormalities of the airways, obstructive sleep apnea, congenital anomalies of the lower respiratory tract, $\mathrm{CHD}$, congenital ear anomalies, gastroesophageal reflux, and deglutition disorders. The best known immunological problems aredecrease in T- and B-lymphocytes; small size of the thymus;reduction in the number of memory $\mathrm{B}$ cells;inadequate response to vaccine; decrease in the number of IgG2, IgG4, and IgM levels; and defects in neutrophil chemotaxis.

\section{Conclusion}

Even though many immunological problems have been defined in patients with DS, the underlying mechanism is not fully understood. Studies about memory cells, T- and B-lymphocytesubsets, and dendritic cells are promising. Nevertheless, further research is needed on this topic.

Conflict of Interest: No conflict of interest was declared by the authors.

Financial Disclosure: The authors declared that this study has received no financial support.

Authorship contributions: Concept - M.C., F.B., T.P.; Design M.C., F.B., T.P.; Supervision - M.C., F.B., T.P.; Materials - M.C., F.B., T.P.; Data collection \&/or processing - M.C., F.B., T.P.; Analysis and/ or interpretation - M.C., F.B., T.P.; Writing - M.C., F.B., T.P.; Critical review - M.C., F.B., T.P.

\section{REFERENCES}

1. Acar M, Zorlu P, Tos T, Koca SB, Senel S. Evaluation of demographic and clinical features of patients with down syndrome: Single center experience. Turkish Journal of Pediatric Disease 2014;8:71-4. [CrossRef]

2. Watts R, Vyas H. An overview of respiratory problems in children with Down's syndrome. Arch Dis Child 2013;98:812-7. [CrossRef]

3. Ram G, Chinen J. Infections and immunodeficiency in Down syndrome. Clin Exp Immunol 2011;164:9-16. [CrossRef]

4. Bloemers BL, Broers CJ, Bont L, Weijerman ME, Gemke RJ, van Furth AM. Increased risk of respiratory tract infections in children with
Down syndrome: the consequence of an altered immune system. Microbes Infect 2010;12:799-808. [CrossRef]

5. Stagliano DR, Nylund CM, Eide MB, Eberly MD. Children with Down syndrome are high-risk for severe respiratory syncytial virus disease. J Pediatr 2015;166:703-9.e2. [CrossRef]

6. Mori M, Morio T, Ito S, Morimoto A, Ota S, Mizuta K, et al. Risks and prevention of severe RS virus infection among children with immunodeficiency and Down's syndrome. J Infect Chemother 2014;20:455-9.

7. Yi H, Lanctôt KL, Bont L, Bloemers BL, Weijerman M, Broers C, et al. Respiratory syncytial virus prophylaxis in Down syndrome: a prospective cohort study. Pediatrics 2014;133:1031-7. [CrossRef]

8. Garrison MM, Jeffries H, Christakis DA. Risk of death for children with down syndrome and sepsis. J Pediatr 2005;147:748-52. [CrossRef]

9. Bertrand P, Navarro H, Caussade S, Holmgren N, Sánchez I. Airway anomalies in children with Down syndrome: endoscopic findings. Pediatr Pulmonol 2003;36:137-41. [CrossRef]

10. Mitchell RB, Call E, Kelly J. Diagnosis and therapy for airway obstruction in children with Down syndrome. Arch Otolaryngol Head Neck Surg 2003;129:642-5. [CrossRef]

11. de Jong AL, Sulek M, Nihill M, Duncan NO, Friedman EM. Tenuous airway in children with trisomy 21. Laryngoscope 1997;107:345-50.

12. McLaughlin FJ, Strieder DJ, Harris GB, Vawter GP, Eraklis AJ. Tracheal bronchus: association with respiratory morbidity in childhood. J Pediatr 1985;106:751-5. [CrossRef]

13. Unal E, Oran B, Baysal T, Baspinar O, Keser M, Karaarslan S, et al. Pulmonary arterial pressure in infants with laryngomalacia. Int J Pediatr Otorhinolaryngol 2006;70:2067-71. [CrossRef]

14. McDowell KM, Craven DI. Pulmonary complications of Down syndrome during childhood. J Pediatr 2011;158:319-25. [CrossRef]

15. Biko DM, Schwartz M, Anupindi SA, Altes TA. Subpleural lung cysts in Down syndrome: prevalence and association with coexisting diagnoses. Pediatr Radiol 2008;38:280-4. [CrossRef]

16. Irving CA, Chaudhari MP. Cardiovascular abnormalities in Down's syndrome: spectrum, management and survival over 22 years. Arch Dis Child 2012;97:326-30. [CrossRef]

17. Faria PF, Nicolau JA, Melek MZ, de Oliveira Nde S, Bermudez BE, Nisihara RM. Association between congenital heart defects and severe infections in children with Down syndrome. Rev Port Cardiol 2014;33:15-8. [CrossRef]

18. Chin CJ, Khami MM, Husein M. A general review of the otolaryngologic manifestations of Down Syndrome. Int J Pediatr Otorhinolaryngol 2014;78:899-904. [CrossRef]

19. Strome M. Down's syndrome: a modern otorhinolaryngological perspective. Laryngoscope 1981;91:1581-94.

20. Shott SR. Down syndrome: common otolaryngologic manifestations. Am J Med Genet C Semin Med Genet 2006;142C:131-40. [CrossRef]

21. Barr E, Dungworth J, Hunter K, McFarlane M, Kubba H. The prevalence of ear, nose and throat disorders in preschool children with Down's syndrome in Glasgow. Scott Med J 2011;56:98-103. [CrossRef]

22. Macchini F, Leva E, Torricelli M, Valadè A. Treating acid reflux disease in patients with Down syndrome: pharmacological and physiological approaches. Clin Exp Gastroenterol 2011;4:19-22. [CrossRef]

23. Delacourt C, Hadchouel A, Toelen J, Rayyan M, de Blic J, Deprest J. Long term respiratory outcomes of congenital diaphragmatic hernia, esophageal atresia, and cardiovascular anomalies. Semin Fetal Neonatal Med 2012;17:105-11. [CrossRef]

24. Abbas AK, Lichtman AHH, Pillai S. Basic Immunology: Functions and Disorders of the Immune System, 4rd ed. Philadelphia: Saunders Elsevier; 2014. 
25. Khocht A, Russell B, Cannon JG, Turner B, Janal M. Phagocytic cell activity and periodontitis in Down syndrome. Oral Dis 2012;18:346-52.

26. Bloemers BL, van Bleek GM, Kimpen JL, Bont L. Distinct abnormalities in the innate immune system of children with Down syndrome. J Pediatr 2010;156:804-9. [CrossRef]

27. Nisihara RM, Utiyama SR, Oliveira NP, Messias-Reason IJ. Mannanbinding lectin deficiency increases the risk of recurrent infections in children with Down's syndrome. Hum Immunol 2010;71:63-6.

28. Bloemers BL, Bont L, de Weger RA, Otto SA, Borghans JA, Tesselaar $K$. Decreased thymic output accounts for decreased naive T cell numbers in children with Down syndrome. J Immunol 2011;186:4500-7.

29. de Hingh YC, van der Vossen PW, Gemen EF, Mulder AB, Hop WC, Brus F, et al. Intrinsic abnormalities of lymphocyte counts in children with down syndrome. J Pediatr 2005;147:744-7. [CrossRef]

30. Kusters MA, Gemen EF, Verstegen RH, Wever PC, DE Vries E. Both normal memory counts and decreased naive cells favor intrinsic defect over early senescence of Down syndrome T lymphocytes. Pediatr Res 2010;67:557-62. [CrossRef]

31. Pellegrini FP, Marinoni M, Frangione V, Tedeschi A, Gandini V, Ciglia $\mathrm{F}$, et al. Down syndrome, autoimmunity and T regulatory cells. Clin Exp Immunol 2012;169:238-43. [CrossRef]
32. Kusters MA, Verstegen RH, Gemen EF, de Vries E. Intrinsic defect of the immune system in children with Down syndrome; a review. Clin Exp Immunol 2009;156:189-93. [CrossRef]

33. Levin S, Schlesinger M, Handzel Z, Hahn T, Altman Y, Czernobilsky B, et al. Thymic deficiency in Down's syndrome. Pediatrics 1979;63:807.

34. Carsetti R, Valentini D, Marcellini V, Scarsella M, Marasco E, Giustini F, et al. Reduced numbers of switched memory B cells with high terminal differentiation potential in Down syndrome. Eur J Immunol 2015;45:903-14. [CrossRef]

35. Joshi AY, Abraham RS, Snyder MR, Boyce TG. Immune evaluation and vaccine responses in Down syndrome: evidence of immunodeficiency? Vaccine 2011;29:5040-6. [CrossRef]

36. Valentini D, Marcellini V, Bianchi S, Villani A, Facchini M, Donatelli I, et al. Generation of switched memory B cells in response to vaccination in Down syndrome children and their siblings. Vaccine 2015;33:668996. [CrossRef]

37. Barradas C, Charlton J, MendoCa P, Lopes AI, Palha M, Trindade JC. $\mathrm{IgG}$ subclasses serum concentrations in a population of children with Down syndrome: comparative study with siblings and general population. Allergol Immunopathol (Madr) 2002;30:57-61. [CrossRef] 